\title{
THE INTRA-UNION CONTROL OF COLLECTIVE BARGAINING
}

\author{
FRANK T. DE VYVER*
}

The bargain made between an employer and his employees has many characteristics setting it apart from bargaining in other phases of business. One of those distinctive characteristics is that the employer ordinarily bargains as an individual or as a corporate person with standardized, well-defined, and centralized control, whereas his workers bargain as an unincorporated association in the management of which varying degrees of democratic control are found. Therefore, in seeking an understanding of the processes of collective bargaining, a study of control within the union becomes important insofar as the location of that control affects the making of an agreement.

Distribution of power between the rarik and file and union representatives assumes importance during three phases of the collective bargaining process: when the original agreement is made, when disputes arise under that agreement, and when, negotiations having reached the breaking point, a strike threatens. On any of these three occasions an employer may find democracy so real within the labor organization that he must deal with officers having no authority save that of leadership, or he may discover autocratic rule so complete that labor racketeering is possible. On the other hand, a worker may find his vote to be of extreme importance for a collective settlement, or he may be forced to accept what his elected representatives claim to be the best possible contract: ${ }^{1}$

\section{Making the Original Agreement}

Among labor organizations two general methods, each carrying a different degree of membership control, are employed in making original agreements. The contract may be negotiated by national, ${ }^{2}$ district, or local officers in accordance with a more or less detailed collective bargaining policy approved by the national convention; or agreements may be made by each local aided, but not restricted, by national officers.

*A.B., 1926, M.A., r927, Oberlin College; M.A., 1930, Ph.D., 1935, Princeton University. Assistant Professor of Economics, Duke University, since 1935. Research Assistant in Labor Problems at the Institute for Research in Social Sciences, University of Virginia, 1928-1930. Co-author of Labor in the Industrial South (1930) and The Development of Economic Society (1937). Contributor to periodicals on labor problems.

${ }^{1}$ See Glocker, The Government of American Trade Unions (1913).

${ }^{2}$ In this paper, when referring to the national organization, the terms national and international will be used synonymously. 
Various combinations and modifications of these general methods have arisen in practice.

In industries with considerable uniformity of product over the entire competitive area and with few producers or perhaps an employer's association with which to negotiate, international authorities usually make agreements for organized labor. ${ }^{3}$ Among C.I.O. affiliates, for instance, bargaining by the Steel Workers' Organizing Committee and by the officers of the United Mine Workers Union provides excellent examples of the method of concluding national agreements with very little local autonomy.

The biennial convention of the United Mine Workers adopts a wage policy containing the basic proposals to be presented to the operators. Meanwhile each of the thirty districts of the union elects wage scale representatives who meet, shortly before wage negotiations begin, with the national president and the district officers to form a policy committee. This large committee is then reduced to a workable unit, usually consisting of three international officers and presidents of the principal districts. For the actual negotiations, the reduced committee meets with a similar group of operators. But the policy committee is informed of progress and must give its approval before the wage agreement is concluded. ${ }^{4}$

Events preceding the recently renewed steel agreement concluded by the Amalgamated Association of Iron, Steel, and Tin Workers of North America, bargaining through the Steel Workers' Organizing Committee, offer a pertinent example of the operation of this method. For the steel union the basic agreement is with the United States Steel Corporation. Each lodge of the union elects a representative to serve on a scale committee which works with the national officers and the employers in a manner similar to the mine workers policy committee. Preceding the last convention held in December, 1937, divers lodges referred 877 resolutions dealing with 25 subjects to the National Wage Scale and Policy Committee. One hundred and sixty-nine of these dealt with various phases of the wage question such as requests for wage increases, individual wage adjustments, annual wages, and abolition of southern and eastern differentials; 66 concerned questions of hours of work; 462 dealt with twelve miscellaneous subjects included in S.W.O.C. contracts, seniority, vacations with pay, closed shop, working conditions, and the like. Finally I30 resolutions expressed confidence in the S.W.O.C. and authorized its members to continue their efforts without stint.

The wage and policy committee, selecting one of the resolutions of confidence, asked for its approval as the convention's instructions to the national officers. Whereupon the convention resolved, in the words of "Lodge No. II8I, Amalgamated Association of Iron, Steel and Tin Workers of North America, and employees of

\footnotetext{
${ }^{3}$ However, national or regional bargaining is not found in all such industries. For instance, the automobile workers have insisted upon the retention of a considerable amount of local autonomy.

'Letter from David J. MeDonald, Secretary-Treasurer of the Steel Workers' Organizing Committee, Jan. 20, 1938. For the wage scale resolution adopted by the International Convention, in January, 1938, sec 49 United Mine Workers J., Feb. 15, 1938, p. 18.
} 
Carnegie-Illinois Steel," that we, "highly appreciate the service rendered on our behalf by the Steel Workers' Organizing Committee, whom we have chosen as representatives of our Union, and as our collective bargaining agents, in dealing with our employer; and Whereas, we recognize the importance of strengthening our Union and the necessity of having the proper leadership to guide it in order that our future may be secure; therefore, Be It Resolved, that we authorize and instruct the Steel Workers' Organizing Committee to continue their services as representatives of our Union, and as our collctive bargaining agents, and that when meeting in con-ference with the representatives of our employers, that they will have full power to secure the best joint wage agreement possible." 5

Armed with this blanket authorization from the duly elected convention the national officers of the S.W.O.C. proceeded to conclude successfully a renewal of their collective bargaining contracts with the United States Steel Corporation.

Another organization well established in such methods of national and regional bargaining is the union of potters, an affiliate of the American Federation of Labor. ${ }^{0}$ Locals of this organization present resolutions regarding wages to the national convention and thence to a "committee on general-ware price list." This group must study "all the 'demands' proposed by the locals and decide which shall be recommended to the convention for adoption and submission to the employers." The convention ordinarily accepts the recommendations of the general-ware price list committee, and afterwards a newly-formed conference committee uses them as their general instructions in their bargaining with the manufacturers' representatives.

In neither of these instances, nor in the bargaining procedure of other similar organizations, are the members polled on the details of the agreement. The policy was adequately summarized in a recent letter from an official of one of the railroad unions connected with the A. F. of $L$. The officer said, in part, that "In the matter of negotiating rules and wages, you can understand that the membership itself does not and cannot keep within their own hands at every stage of the proceedings, the right to-instruct their representatives on compromise settlements. In other words, if ise representatives of the men, in dealing with railroad managements upon working rules or wage matters can reach a settlement which they feel is advisable, they make such settlement without submitting the matter to a referendum of the membership."

On the other hand the members of the other group of unions, that is, the ones bargaining locally, retain varying degrees of control over the formulation of the original contract, ranging from a requirement that local bargaining must follow a general outline passed by the national convention, to the requirement that the local members must pass upon every move made by their negotiators.

Many union constitutions contain no provisions for making agreements. Under

\footnotetext{
setter from David J. McDonald, supra note 4; Report of the National Wage Scale and Policy Committee to the 1937 Convention of the S.W.O.C.; 2 Strel Labor, DeC. 31, I937.

- For a history of this union's activities, see McCabe, Nattonal Collective Baroainino in the PotTERy INDUSTRY (1932). A recent report upon successful bargaining in the pottery industry is given in 2 LABOR ReL. Rep. March 14, 1938,s p. 48.

${ }^{7} \mathrm{MCCABE}$, op. cit., supra note 6, at 124 .
} 
such circumstances the local union probably retains autonomy. Other unions, however, specifically provide for almost complete local autonomy in their constitutions or by-laws. The United Electrical, Radio and Machine Workers of America offer an interesting example of the former; the United Boot and Shoe Workers is typical of the latter.

Nothing in the Electrical Workers' constitution specifically outlines bargaining procedure, yet the national organization in fact guides the locals. A local elects its own officers and committees to act for it at all times. When a contract is to be arranged the executive committee of the local prepares tentative demands for submission to the membership, but on submission those demands may be changed by a majority vote. Armed with the approved demands, the committee goes to the management for negotiation. A representative of the International office often accompanies them but neither that representative nor any other person can constitutionally negotiate alone. The negotiators report their progress to the union from time to time, occasionally receiving further instructions. Upon the completion of the agreement it is subject to ratification by a majority vote of the local union. ${ }^{8}$

The Boot and Shoe Workers' Union provides a similar procedure in its constitution. Though Section 3 designates the General Union meeting in convention as the supreme head of the organization, the constitution imposes on the local executive board the duty to "adjust wages and conditions of employment, subject to the control of the local union." The national organization merely offers its assistance to the local executive boards through a general price-list committee. Moreover, a further section reiterates that the general price-list committee should not abridge the rights of the local boards. ${ }^{9}$

More uniform contracts are sometimes obtained without abolition of local control, by a system followed, among others, by the Amalgamated Clothing Workers and the American Federation of Hosiery Workers.

For new contracts in particular the Amalgamated ordinarily negotiates through a representative of the national office, with a local committee present at all times. However, any tentative new or renewal agreement is presented to the local for approval. If the members refuse to ratify, the negotiators resume their efforts. The national representatives, on the other hand, do "exercise leadership," pointing out to the members "the state of employment, competition, prevailing wage scales, and other relevant data," upon the basis of which the decision must be made. ${ }^{10}$

- Most of the other unions studied ${ }^{11}$ whose constitutions feature references to collective bargaining provide that the national officers must approve any agreement made by a local. Despite the silence of the rules such provisions probably mean that in practice the national officers participate in the agreements in various degrees. The

${ }^{8}$ Letter from Wiliam Mitchell, Research Director, United Exectrical, Radio, and Machine Workers of America, Jan. 13, 1938.

'Boot and Shoc Workers' Union, Constitution (1933) §16.

${ }^{10}$ Letter from Gladys Dickason, Director of Research, Amalgamated Clothing Wòrkers of America, Jan. 15,1938 .

21 The constitutions of thirty-four unions were studied in the preparation of this report. 
constitutions themselves, however, seek to provide national union rules even where local bargaining exists by erecting a variety of restrictions upon local autonomy, and if the national officers go no further, they are required to certify the constitutionality of the agreement.

Those constitutional limitations on locals in negotiating agreements are of many varieties. Several old-line craft unions provide uniform apprentice rules that must be included in each contract. The same group often insist that a uniform rate of pay be provided. The plumbers urge all locals to adopt the eight-hour day and in their constitution make the additional provision that "no financial aid will be rendered to any local going on strike for more wages whose hours of labor are more than eight on building work."12 The Bricklayers', Masons', and Plasterers' Union requires that arbitration of disputes be provided in all contracts. ${ }^{13}$ Centralized control over agreements has achieved the same result for the Amalgamated Association of Street, Electric Railway and Motor Coach Employes of America. ${ }^{14}$

The constitution of the Pressmen's Union contains a general provision requiring the Board of Directors to supervise all contracts likely to affect "the interests of the International Union or of any subordinate union thereof, or of any person affiliated therewith. ..." A few specific matters follow such as the length of time for contracts, a provision about offset presses and one about so-called "struck-work."15 Similarly, nine sections of an article in the constitution of the Typographical Union make specific provisions for all local contracts, though wages and other working conditions not mentioned are left to local determination. Because "the proposed contract must conform with provisions of international law . . . it will be submitted to the President of the International Typographical Union for his approval." This international, as well as many others, furnishes a standard form of contract for the use of its locals. ${ }^{16}$

Obviously no generalization can summarize the extent of democratic control in the making of trade agreements. In many instances, whatever the constitutional provisions, actual procedure will depend upon the interpretation thereof by the national officers, for instance, whether "approval" means passive signing, or forcing local compliance with the ideas of the national officers. Moreover, local autonomy depends more upon the nature of the industry involved than upon any preconceived ideas of democracy. ${ }^{17}$ For instance, the Newspaper Guild recognizes that local requirements necessitate local adjustments, in providing for local autonomy even for contracts with

${ }^{12}$ United Ass'n of Journeymen Plumbers and Steamfitters, Constitution (1928) $\$ 145$.

${ }^{23}$ Bricklayers, Masons and Plasterers' Internat'l Union of America, Constitution (1936) art. 14, $8 \mathrm{I}$.

14 Schmidt, Industrial Relattons in Urban Transportation (1937) 194.

${ }^{25}$ Internat'l Printing Pressmen and Assistants' Union of N. A., Constitution (1933) art. 15.

${ }^{10}$ Internat'l Typographical Union, Book of Laws (1938) 96; letter from Woodruff Randolph, Secretary. Treasurer, Jan. $13,1938$.

${ }^{27}$ Recent decisions of the National Labor Relations Board may affect the extent of the coverage of the bargaining contract. For instance, in a case involving the Waukegan plant of American Steel and Wirc Company, a subsidiary of the United States Steel Corp., the Board coneluded that the individual plant was not the proper unit for collective bargaining. 2 LABOR REL. ReP., March 14 , 1938, p. 51. A similar decision was rendered in the American Woolen Co. case, 1 id., Feb. 14, 1938, p. 655. 
syndicates and press associations when "the bargaining problems are shown to be of local nature."18 Coal, glass, steel, and railroad workers bargain through their national unions; building tradesmen, textile workers in some branches, and many others whose problems are often local provide for local bargaining or at least local acceptance. On the other hand, the fact that the constitutions of such industrial unions as the automobile workers and the aluminum workers provide a considerable degree of local autonomy is an indication that the struggles involved in making the constitutions play their part in determining how far democracy shall go.

\section{Setiling Disputes Arising Under An Agreement}

Provisions for settling minor disputes arising under agreements are more likely to be found in the agreements themselves than in the national constitutions. Nevertheless, since such provisions ordinarily place authority in a selected group rather than in the entire membership, some constitutions contain specific details of procedure, while others treat the subject in a general way.

Usually, if the subject is mentioned, the constitutions require that worker grievances be presented to the local union or to the local or district executive committee. An aggrieved carpenter, for instance, first takes his case to the local. The local appoints a conference committee which endeavors to settle with the employer; but if no agreement can thus be reached the general president or his agent is authorized to try to settle the dispute by negotiation or arbitration. ${ }^{19}$ Other unions, both old and new, insist in their constitutions that all honorable means be tried before a break with the employer is made and that the national president must be called upon to attempt settlement.

Some organizations require that all disputes shall be submitted to so-called arbitration committees, which are really joint committees for settling grievances. The bricklayers, for example, for the past thirty-five years, have provided constitutionally for the election of members to a joint committee with the duty of undertaking the settlement of any dispute arising. ${ }^{20}$ Though the Typographical Union makes no constitutional provision and such matters are left to the locals, the usual agreement nevertheless requires the joint committee method for settling disputes under the agreement. $^{21}$ Since 1891 the Molders' contract with the employers has contained a similar clause..$^{22}$

The shop committee or shop steward system is a plan recommended or required by several industrial nationals. One of the suggested standing rules for C.I.O. affliated unions requires provision for a shop committee, while the automobile workers' constitution, among others, provides that each local in its by-laws shall

${ }^{25}$ American Newspaper Guild, Constitution (1937) art. 18, 85.

${ }^{20}$ United Brotherhood of Carpenters and Joiners of America, Constitution (1937) \$59.

${ }^{20}$ Bricklayers, Masons and Plasterers' Internat'l Union of America, Constitution (1936) art. I4; letter from R. J. Gray, International Secretary, Jan. 13, 1938.

${ }^{20}$ Letter from Woodruff Randolph, supra note 16 .

2" Conference Agreements between Internat'l Molders' Union of North America and Manufacturers' Protective and Development Ass'n. 
establish regulations concerning the shop stewards. ${ }^{23}$ Another C.I.O. affiliate, the United Electrical, Radio, and Machine Workers of America, has published an educational bulletin in which the shop steward system, though not held binding on the locals, is suggested as a method of handling complaints. ${ }^{24}$

Some union constitutions and agreements, though they make no mention of preliminary negotiations, provide for arbitration of disputes arising under an agreement. Two such are those of the Amalgamated Association of Street, Electric Railway, and Motor Coach Employes of America, and the Typographical Union. The former provides that all disputes failing to be settled otherwise are subject to arbitration. ${ }^{2 \sigma}$ Union recognition, of course, cannot be arbitrated. Locals of the printers can provide for arbitration by mutual agreement though in no case can the laws of the international be submitted for such decision. ${ }^{28}$

The Maritime Union deprives its locals on board ship of their right to strike, ${ }^{27}$ and its recently-signed Black Diamond agreement calls for arbitration in port of all disputes arising under the agreement. ${ }^{28}$ Detailed provisions for establishing a board are provided and its decisions declared to be binding. Similar provisions are found in the standard contract of the Office Workers' union. The current bargaining schedule of the Newspaper Guild, on the other hand, provides that no contract shall make provision for compulsory arbitration.

Another paper in this symposium discusses the efficacy of these various methods for settling disputes under agreements. ${ }^{29}$ Suffice it here to point out that membership control over minor disputes is ordinarily delegated to shop committees, impartial chairmen, joint committees, or arbitrators. The individual worker must give up his rights for the greater good, and even the local union must be willing to part with some of its authority before the problem of settling disputes.

\section{The Control of Strikes}

Since the rise of international unions in the seventies' and eighties' of the last century, the control of strikes has been one of the major problems confronting organized labor. ${ }^{30}$ In those early days, says Dr. Glocker, "When the international unions exercised little or no control over strikes, the local unions almost invariably entered blindly into utterly hopeless conflicts against reductions in wages during industrial depressions."31 Leaders of the movement saw that if resources were not to be dissipated, local unions would have to rid themselves of the bad habit of striking upon

-Internat'1 Union, United Auto. Workers of America, Constitution (1937) art. 30, 54.

26 The Shop Steward System and Local Union Problems, Pamphlet No. I (1937).

-Amalgamated Ass'n of Street, Electric Railway and Motor Coach Employes of America, Constitution (1937) $\$$ ז27.

${ }^{\infty}$ Internat'l Typographical Union, Book of Laws (1938), Gen. Laws, art. 2.

"National Maritime Union of America, Constitution (1937) art. 24, 54.

Agreement, signed Nov. 6, 1937, art. 7 .

- McCabe, Machinery for the Adjustment of Disputes under New Collective Agreements, supra p. $26 \mathrm{x}$.

${ }^{20}$ See Janes, The Control of Strikes in American Trade Unions (igi6).

" GLOCKER, op. cit. supra note I, at IIO. 
every occasion. Similarly, newly formed locals in large-scale industry have occasionally embarrassed their national officials by conducting unauthorized strikes in complete disregard of agreements.

The control of strikes is a two-fold problem involving, on the one hand, the calling of strikes by the national organization regardless of the wishes of the locals involved, and, on the other hand, the national veto of strikes sanctioned by democratic procedure within the locals themselves. A few of the constitutions studied provide for the former situation; most of them contain very clear and complete provisions concerning the latter.

Sections of union constitutions dealing with strikes range from mere statements that the national organization must sanction all strikes, to detailed summaries of procedure. In general, the national control ranges from the power to call as well as veto strikes, to the requirement that the executive board of the union be kept informed of developments.

Of the unions studied, the pressmen's constitution contains provisions delegating the international organization the most complete control over stoppages. ${ }^{32}$ If a local of that union unsuccessfully demands changes in wages or working conditions the members may ask the international union for strike sanction. This request must include a "full and complete statement of the causes for the proposed strike" together with an account of the action thus far taken. Copies of the request are sent to each of the five members of the board of directors who are instructed by the constitution to forward their decision immediately to the international president, "whether they sanction the strike or not." If a local does not follow this plan it may be disciplined by fine, suspension, or the revocation of its" charter.

With this sanction, the local president calls a meeting, and if authorized by threefourths of the members entitled to vote, must inform each member of the board of directors that the strike is in process. Benefits are then payable to the strikers for a period of eight weeks unless the board decides to continue longer.

Union laws provide further that no strike benefits will be paid to a local striking without sanction and that such local is automatically suspended. Furthermore, if the unauthorized strike breaks a contract with an employer, the board of directors is authorized "to call upon members from other local unions to fulfill the contractual obligations of the striking local." Any local refusing to comply with such a request may itself be suspended.

Strike control by the board of directors is made complete by giving them the authority to call out any subordinate union if such action will forward the settlement of a dispute. In this instance, if a subordinate union refuses to participate, it may be fined not less than $\$ 250$ nor more than $\$ 500$.

The more usual constitutional provisions call for slightly less centralized power in the hands of the international officers than exists with the pressmen. Ordinarily

\footnotetext{
- Internat'l Printing Pressmen and Assistants' Union of North America, Constitution and Laws (1933) arts. 5,36 .
} 
two-thirds or three-fourths of the members attending a called meeting must indicate their will by secret ballot. The international officers are then asked to sanction the proposed strike. In extreme emergencies the international president may grant approval, but usually no strike benefits will be paid and the local may be expelled unless a majority of the executive council feels that the stoppage is justified. Power is often given to the national officers to call off a strike if they feel "that it is unwise to longer continue" it. If they so decide, strike assistance ceases. Such veto power, however, is not ordinarily accompanied by the right to call strikes without consulting the local involved. Many constitutions are silent on that matter entirely which means that the national has no such power; even the international officers of the automobile and aluminum workers' unions can declare a general strike only "in cases of great emergency when the existence of the international union is involved together with the economic and social standing of our membership. . . ."33

Sanction of strikes by the members with the power to declare them vested in the international officers is found among a group of unions whose membership is likely to be widely scattered. Among railroad unions and in the National Maritime Union, a major strike can only be called after a strike vote has been taken. Nor does the authorization of a strike by the referendum bind the national or district officers, although a vote against a strike does. The Mine, Mill and Smelter Workers' constitution provides, for instance, that the strike vote is only an expression and that the authority to call the strike is vested in the district or international executive board to be used only after everything else has failed. ${ }^{34}$ In this connection Professor McIsaac has said of the railroad telegraphers, "The strike vote is naturally used as a bargaining device many times when the employees have little serious intention of striking."35

A unique combination of central authority and local autonomy is found in the strike provisions of the Boot and Shoe Workers' constitution. ${ }^{36}$ If the local desires aid from the national, it must consult the general president and be guided by his advice, for only if he and the committee of the general executive board give their approval can national funds be used. On the other hand, if a local strikes on its own responsibility there-is no threat of expulsion unless the strike violates a contract. At the same time, however, the general executive board may declare a strike, with financial aid, in any factory at any time.

Generally speaking, national unions have been gaining in control over the strike activities of the locals. It is the exception, however, to find the national organization invested with the constitutional right to call out any local whether or not that local is engaged in a dispute. The control of the national is enforced through control of the purse strings since only exceptional locals will be able to pay strike benefits very

${ }^{s}$ Internat'l Union, United Auto. Workers of America, Constitution (1937) art. 16, 55; Aluminum - Workers of America, Constitution (1937) art. 13, \$5.

"st Internat'l Union of Mine, Mill and Smelter Workers, Constitution (1937) art. 8, \$1.

${ }^{*}$ McIsac, The Order of Railroas Telegraphers (1933) 15.

${ }^{*}$ Boot and Shoe Workers' Union, Constitution (1933) \$\$85-90, 93, 94 . 
long without outside aid. The value of strike benefits as an important control feature depends upon the strength of the local union's desire for financial aid. That desire, in turn, is affected by the certainty of the promised assistance. During their early history many internationals solicited funds to finance each strike. At the present time many unions provide constitutionally for strike benefit payments ranging from five to ten dollars per week and, in addition, require that a fixed percentage of all dues shall be paid into the strike or defense fund. Furthermore, the threat of suspension may be a very real danger to members of those many unions which pay death, accident, health, old age, or unemployment benefits to members in good standing. Despite these sanctions, occasionally, the local unions refuse to abide by national decisions, as recently among a group of hosiery workers. ${ }^{37}$ In such instances expelling may serve only to stimulate dual unionism. Usually, however, the national is able to control strikes if it will.

\section{JuRisdictional Disputes}

In an oft-quoted passage Sidney and Beatrice Webb remark that "It" is no exaggeration to say that to competition between overlapping unions is to be attributed nine-tenths of the ineffectiveness of the Trade Union world."38 Certainly the effectiveness of collective bargaining is weakened, if not destroyed, when an employer is confronted with conflicting demands for recognition. Some writers even maintain that jurisdictional disputes harm rather than help the workers and have persisted only because of the vested interest of union officers in their jobs and the fear of losing votes and prestige at the annual Federation conventions. ${ }^{39}$

Recent dual unionism has brought the problem more clearly to public attention. It is general knowledge, for instance, that the automobile workers union, a C.I.O. affliate, has organized workers over whom the machinists, carpenters, and other internationals still claim jurisdiction; and that the carpenters claim jurisdiction over the furniture workers now being organized by the C.I.O. Jurisdictional disputes, however, are not the result of recent labor history; they have occurred and persisted since the establishment of unions and with increasing vigor as craft lines have become more and more blurred in modern industry.

Various methods, none entirely successful, have been devised to handle such disputes. Union constitutions are the starting point of the difficulties since each contains a more or less detailed statement of the territory and workers claimed. The carpenters, ${ }^{40}$ for example, after stating that their union includes all branches of the carpenter and joiner trade, list in a succeeding section, fourteen distinct subdivisions

\footnotetext{
n This four-day unauthorized strike ended after the national officers had promised to appeal the award of the arbitration board. See 2 LABOR REL. REP., March 7, 1938, p. 7.

${ }_{80}$ WeBB \& WeBb, Industrial Democracy (1920) r2I.

${ }^{*}$ For discussion of this and other problems of jurisdictional conflicts, see Daugherty, LABor Probzems in AMerican Industry (1936); Brooks, When Labor Organizes (1937) and Whitney, Jurisdiction in ANERICAN BuILDING-TRADES UNIONS (I914).

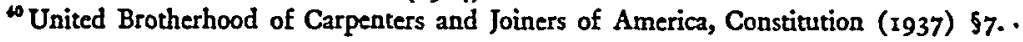


including furniture workers, ship carpenters, joiners, and caulkers, and shipwrights. Most of the constitutions do not indulge in such detailed specifications; and, having outlined their boundaries, the unions proceed to organize within those boundaries, oblivious to the fact that others may include the same territory.

A federation, however, cannot long forget such matters. In fact, one of the principal tasks of the American Federation of Labor has been to settle disputes between affiliated unions, while forbidding membership to any union claiming jurisdiction overlapping that of a group already associated with the Federation. The A. F. of L. has sought to aid in settling jurisdictional squabbles by promoting voluntary interunion agreements, amalgamations, and departmental alliances, and, according to Dr. Lorwin's study of the Federation, such plans have to some extent mitigated the evil. ${ }^{41}$

On the other hand the status of the American Federation of Labor as a federation limits its power in forcing settlements between associated unions to moral suasion. When a powerful organization like the carpenters "take their toys and go home"4 because a decision is made against them, there is nothing for the Federation to do but coax the pouting child, even with a candy bribe. Obviously when new unions arise claiming jurisdiction in fields already staked out, the Federation is still more impotent.

The passage of the National Labor Relations Act has seemed to some to offer a new way for dealing with these jurisdictional disputes. In fact, in his recent book, Professor Brooks maintains that the "elections of the National Labor Relations Board to determine the union which the workers want to represent them is actually a method of settling jurisdictional conflicts by democratic action." ${ }^{33}$ When the dispute is between unions affiliated with different Federations, the Board has evidently been willing to settle by voting. For instance, in a case decided February $2 \mathrm{r}$, x938, involving the Armour Company, ${ }^{44}$ the Board decided that machinists employed at a large meat packing plant could constitute either a separate unit or part of the plant unit of production and maintenance employees depending on the desires of the machinists. Since the majority of the machinists voted for the craft unit they were found to constitute a separate unit.

However, in conflicts involving locals of unions both affliated with. the same Federation the Board has maintained a hands-off attitude. Thus they refused to decide whether the machine fixers in a tobacco plant are under the jurisdiction of the Tobacco Workers' International Union or the International Association of Machinists, on the grounds that the American Federation of Labor provides machinery for settling such quarrels.45 In another similar case involving aluminum workers, the Board said in effect that when the question was not who shall represent

\footnotetext{
"Lorwin, The amerucan Federation of Labor (1933).

Daugherty, op. cit. supra note 39, at p. $512 . \quad$ " Brooks, op. cit. supra note 39 , at p. $260 \mathrm{n}$.

*Armour and Co., 2 Labor Res. Rep., March 7, 1938, p. 20.

${ }^{25}$ The Axton-Fisher Tobacco Co., Brown and Williamson Tobacco Corp., 1 N.L.R.B. $60_{4}$ (x936).
} 
the employees but who shall represent the union the National Labor Relations Board would take no hand. ${ }^{46}$

Meanwhile, in such difficulties, the rank and file apparently have little influence on the final decision. The carpenters' constitution, for example, gives to the general executive board the right "to enter into agreement with sister organizations with reference to jurisdiction over work." 47 Furthermore, in the several agreements between the International Printing Pressmen's Union of North America, and other unions like the machinists, the presidents or other representatives of the organizations are given the power to settle the disputes. ${ }^{48}$

Study of labor constitutions reveals the wide disparity among international unions with respect to the control the central organization exercises. The original collective bargaining agreement, for example, is sometimes concluded by the nationals, sometimes by the local with the advice of the national officers, and sometimes by the local bound by few restrictions. Similarly disputes arising under the agreement are often left to the jurisdiction of the local though some organizations retain complete supervision. When a local wishes to strike, however, it usually must receive sanction from the international union before strike benefits are available.

Economic and historic reasons lie behind these differences in centralization as provided in trade union constitutions but in discussing constitutional provisions controlling the collective bargaining agreement, it must be borne in mind that, as with most such written documents, labor constitutions are subject to stretching by interpretation. The executive board is ordinarily given the right to interpret the rules subject only to reversal by the convention. Under such circumstances rank-and-file participation in the bargaining process depends largely upon the quality of the national leadership and upon what that group accomplishes. In other words, so long as the national, district, or local officers deliver the goods to the satisfaction of the workers, democracy is not an issue and autocratic control, even dishonest control, is likely to be condoned.

Finally, since industrial conflict often requires immediate decision, and since union officials realize that members will judge them by their accomplishments, in the exigencies of the labor struggle the "constitutional lawyer" is likely to be consulted only after the struggle is over and the contract signed. As one union official wrote in a recent letter, "At times, situations arise where it is advisable to depart widely from the constitutional bargaining program."

\footnotetext{
${ }^{16}$ Aluminum Co. of America, I N.L.R.B. 530 (1936). That in so doing the Board acted within the law was recently decided by a federal court. California State Brewers Institute v. International Brotherhood of Teamsters, Chauffeurs, Stablemen, I9 F. Supp. 824 (N. D. Calif. 1937).

"United Brotherhood of Carpenters and Joiners of America, Constitution (1937) \$15.

'International Printing Pressmen and Assistants' Union of North America, Constitution and Laws (1933) p. 220.
} 